\title{
Exploring the Attitude to Climate Change and Socio-Ecologically Responsible Consumption of the Slovaks
}

DOI 10.18267/pr.2021.krn.4816.1

\author{
Marián Čvirik ${ }^{1}$ - Mária Dzurová ${ }^{2}$ - Diana Ölveczká ${ }^{3}$ \\ ORCID iD: 0000-0003-4701-15431 ${ }^{1}$, not available ${ }^{2}$, not available ${ }^{3}$ \\ marian.cvirik@euba.sk, maria.dzurova@euba.sk, olveczka3@uniba.sk \\ 1,2 University of Economics in Bratislava, Faculty of Commerce, Department of \\ Marketing \\ Bratislava, Slovakia \\ ${ }^{3}$ Comenius University in Bratislava, Faculty of Natural Sciences, Department of \\ Geology and Paleontology \\ Bratislava, Slovakia
}

\begin{abstract}
The aim of the presented article is fivefold: (1) measuring Slovaks' attitudes to climate change, (2) examining the influence of demographic factors on this rate, (3) measuring socio-ecological behaviour of Slovaks, as well as (4) examining the impact of demographic factors on this rate and (5) the relationship of Slovaks' attitudes to climate change and their socio-ecological behaviour. The study is supported by a primary survey based on 384 respondents who form a quota sample. Based on the objectives of the article, we created research questions and hypotheses, which we test based on ANOVA-test and linear regression analysis. In this work we use two scales - ACC and SRCB scale. Based on the results, we can state below-average to average interest of Slovaks in environmental behaviour and ecologically social sustainable consumption. The results of the study can be used in ecological, social, environmental as well as educational, marketing, and ecological areas.
\end{abstract}

Keywords: socially responsible consumption behaviour, consumer behaviour, ecology, climate change

JEL Classification codes: Q57, D91, M30

\section{INTRODUCTION}

One of the greatest challenges for the world in the $21^{\text {st }}$ century is the shift of selfish and consumerist behaviour to environmentally conscious consumer behaviour and long-term sustainable consumption. In recent years, consumers have begun to realize the impact of their behaviour on the environment; especially the stages of shopping and post-buying one. The authors Abdul Wahid et al., (2011) concluded that consumer pressure is gradually forcing companies to offer products that are environmentally friendly. If companies ignore this pressure, they risk losing their competitive advantage. It is important for both producers and traders to realize that among the classic purchasing factors such as price, quality and country of origin, the ecological side of the product also comes to the fore (Binninger and Robert, 2008; Zakersalehi and Zakersalehi, 2012). Recent surveys show there is a growing segment of consumers who prefer the environmental aspect to the price (Sua et al., 2012).

Many scientific and professional articles focus on this issue from the perspective of companies. However, it is important to realize that one of the main players in the market are households 
(consumers), and if companies want to be successful, they must be based primarily on the preferences and interests of their customers, who represent the alpha and omega of business.

Among the basic aspects that need to be examined in relation to consumer behaviour and ecological, environmental, and socially responsible behaviour are consumer attitudes, willingness to accept / reject ecological lifestyle (pro-environmental behaviour) and to master the basic elements of socially responsible consumption in consumer behaviour. It should be added that these aspects are conditioned by consumer knowledge as well as basic demographic factors.

The article has high goals that it examines in the conditions of Slovakia based on the primary survey. In general, it can be stated that there is no one general concept that would cover all aspects of the issue. Therefore, we will take a closer look at these aspects individually.

\section{LITERATURE REVIEW}

The topic of ecological, environmental, and social awareness in the context of consumer behaviour represents a new concept that deserves the closer attention of scientists and experts. As important authors (e.g., Courtenay-Hall and Rogers, 2002; Gough, 2002) emphasize, a model of consumer behaviour that encompasses all these aspects can only be interpreted in certain dimensions. As several models suggest, the basis for conscious behaviour is a sufficient cognitive level of the consumer which is subsequently reflected in his attitudes and leads to pro-environmental behaviour (Chan, 1998).

Knowledge is the basis of the presented model, but this cognitive component often follows the affective one (most often a feeling of fear and a sense of belonging). According to a study by Fliegenschnee and Schelakowsky (1998), it can be stated that unless the cognitive component manifests itself effectively (internal motives and feelings do not arise), knowledge does not provide a sufficient stimulus.

The cognitive and affective components can shape consumer attitudes. Attitudes can be understood as beliefs that can create a certain action or beliefs that affect us so that we do not create an act. We understand deed and action as a conative component that is the result of this model. Diekmann and Franzen (1997) point out that the more consumers must sacrifice (higher price, more time to search for products) in the context of environmental products, the lower the positive impact of attitude as well as the ability to act. The results of the survey shown that only in the category of small victims are consumers willing to act strongly proenvironmentally.

Roberts (1995, 1996a, 1996b) states that consumers are increasingly aware of their social and environmental responsibilities, which is reflected in their purchasing decisions.

Lifestyle in the context of the environment and awareness creates completely new areas. Currently, the concept is often mentioned socially responsible consumption. Webster (1975) defined socially conscious consumer "as a consumer who takes into account the public consequences of his or her private consumption or who attempts to use his or her purchasing power to bring about social change". Mohr et al. (2001) I understand socially responsible consumer "as a person basing his or her acquisition, usage and disposition of products on a desire to minimize or eliminate any harmful effects and maximize the long-run beneficial impact on society ${ }_{\prime \prime}$.

Socially responsible consumption is defined as "those consumer behaviours and purchase decisions which are related to environmental and resource-related problems and are motivated not only by a desire to satisfy personal needs but also by a concern for the welfare of society in general" (Antil 1984; Antil and Bennett 1979). 
There are several studies that dealt with this issue, but only a small part took place in Slovakia. In Hungary, for example, several studies have addressed the issue (Székely et al., 2011; Csutora, 2012; Kraiciné Szokoly and Czippán, 2011), which point to the acute need to examine the issue and influence consumers to adopt pro-environmental behaviour.

\section{METHODOLOGY}

The aim of the article is fivefold: (1) measuring Slovaks' attitudes to climate change (based on Attitudes to Climate Changes Scale), and also (2) examining the influence of demographic factors on this rate, (3) measuring socio-ecological behaviour of Slovaks (based on Socially Responsible Consumption Behaviour Scale), as well as (4) examining the impact of demographic factors on this rate. At the same time, we will examine (5) the relationship of Slovaks' attitudes to climate change and their socio - ecological behaviour.

\section{Creating research questions (RQ) and hypotheses $(\mathrm{H})$ :}

Based on the stated goals, we created research questions and hypotheses:

RQ1: What is the rate of attitudes towards climate change? (based on ACC scale)

RQ2: What is the level of ecologically and socially responsible consumption? (based on SRCB)

RQ3: What effect do the selected demographic factors have on the ACC scale?

H1a: There is a relationship between the measured ACC value and age.

H1b: There is a relationship between the measured ACC value and gender.

RQ4: What effect do the selected demographic factors have on the SRCB scale?

H2a: There is a relationship between the measured value of the SRCB and age.

$H 2 b$ : There is a relationship between the measured value of SRCB and gender.

RQ5: What is the direction and intensity of the relationship between ACC scale and SRCB scale?

H3: There is a relationship between the ACC value and the SRCB.

\subsection{Sampling and data collection procedures}

In the primary survey, we used a quantitative inquiry method to collect data. Basic population will be defined as Slovak consumers older than 15 years. There are several reasons for determining the lower limit of our base population for 15 years. As stated by Badzińska (2011) most important is that respondents older than 15 years have their own money and often decides on their own, without the involvement of parents about their purchases, deeds, and create their own attitudes as opposed to respondents younger than 15-year-old. Overall, from this age on, consumers perceive the world and have sufficient education to understand the environmental aspects of their behaviour.

Since the aim of the article is to examine demographic variables, we chose the method of nonprobability sample - Quota sample, which captures the demographic characteristics of the basic set. Based on the choice of this type of data collection, the findings will be more accurate and relevant.

First stage was to determine quotas in basic population (see Tab. 1). Quotas for research were age and gender. Second stage was to apply quotas to create the sample (based on judgement and random sample - walk method, where the researcher addressed respondents according 
to key factors and randomly found respondents who matched the characteristics of the target group) what can be seen in the Tab. 1 . The basis for our research was 384 respondents.

Tab. 1 Quotas and their application

\begin{tabular}{llcc}
\hline Factors & & Quotas [\%] & Quotas applied [pcs.] \\
\hline \multirow{2}{*}{ Gender } & Men & 48.8 & 187 \\
& Women & 51.2 & 197 \\
\hline \multirow{3}{*}{ Age } & $15-39$ years old & 40.31 & 155 \\
& $40-64$ years old & 41.3 & 159 \\
& Older than 65 years & 18.39 & 70 \\
\hline \multirow{2}{*}{$\Sigma$} & & 100 & 384 \\
\hline
\end{tabular}

Source: own calculation based on SOSR (2020).

As shown in Tab. 1, the sample surveyed represents a representative sample of the population of Slovakia older than 15 years according to the following quotas: age and gender. For a sample of 384 respondents, the maximum statistical error (with a $95 \%$ confidence probability) was around $5 \%$.

\subsection{Primary research - basic parameters}

We conducted a standardized inquiry conducted by a research tool - a questionnaire. The questionnaire was created in a print and online form and consisted of three parts:

The first part of questionnaire focused on measuring the attitudes of Slovak consumers to climate change. This measurement was performed based on the ACC scale tool (Attitudes to Climate Change scale), which was created by Čvirik and Ölveczká (2020a) and tested on 500 respondents. The scale contains twelve statements, to which the respondent responds on a five-point Likert scale. The authors demonstrated a high degree of reliability and population, and a strong internal consistency of the scale (total Cronbach's alpha was 0.827), as well as a low rate of standard deviation for individual statements (max. 0.833 points). Overall, the presented tool appears as suitable for further research in the field of ecology and consumer behaviour, so we decided to adapt it in our article. The mean values, standard deviations and for individual ACC scale statements were recorded in the Tab. 2.

Tab. 2 ACC scale

\begin{tabular}{|c|c|c|c|}
\hline ACC scale items* & $\begin{array}{l}\text { Mean } \\
\text { scores }\end{array}$ & $\begin{array}{l}\text { Standard } \\
\text { deviations }\end{array}$ & $\begin{array}{l}\text { Cronbach's } \\
\text { alpha*** }\end{array}$ \\
\hline 1. The global climate is changing. & 2.88 & 1.35 & 0.781 \\
\hline 2. Man is the cause of climate change. & 2.39 & 1.01 & 0.805 \\
\hline 3. The climate in Slovakia is changing significantly. & 2.63 & 1.31 & 0.809 \\
\hline $\begin{array}{l}\text { 4. Climate change does not exist, it is just conspiracy theories. } \\
* *\end{array}$ & 2.17 & 0.88 & 0.810 \\
\hline $\begin{array}{l}\text { 5. The importance of examining climate change is } \\
\text { overestimated. ** }\end{array}$ & 2.55 & 1.29 & 0.780 \\
\hline 6. The effects of climate change do not affect life on Earth. ** & 2.21 & 0.97 & 0.807 \\
\hline 7. I am afraid of climate change and its consequences. & 2.31 & 1.31 & 0.780 \\
\hline
\end{tabular}




\begin{tabular}{l|c|c|c}
\hline ACC scale items* & $\begin{array}{l}\text { Mean } \\
\text { scores }\end{array}$ & $\begin{array}{l}\text { Standard } \\
\text { deviations }\end{array}$ & $\begin{array}{l}\text { Cronbach's } \\
\text { alpha*** }\end{array}$ \\
\hline $\begin{array}{l}\text { 8. I try to use ecological modes of transport. } \\
\text { 9. It is warmer in Slovakia every year, which is caused by } \\
\text { climate change. }\end{array}$ & 2.67 & 1.70 & 0.795 \\
$\begin{array}{l}\text { 10. It does not bother me that the world's seas and oceans are } \\
\text { rising, because it does not affect me at all. ** }\end{array}$ & 2.33 & 1.16 & 0.808 \\
$\begin{array}{l}\text { 11. I would be willing to pay more for products that do not } \\
\text { contribute to climate change. }\end{array}$ & 2.15 & 1.09 & 0.790 \\
$\begin{array}{l}\text { 12. Urban public transport is greener, emits less emissions and } \\
\text { that is why I prefer it. }\end{array}$ & 2.47 & 1.22 & 0.804 \\
\hline
\end{tabular}

Note: * Used 5-degree Likert scale ( 1 = strong disagreement, 5 = strong agreement).

** Negative / opposite evaluation.

$* * *$ Overall Cronbach's alpha $=0.813$

Source: Own calculations based on a scale from Čvirik and Ölveczká, 2020a

In the second part of the questionnaire we focus on measuring responsible consumption and environmental awareness in the consumer behaviour of Slovaks. To achieve this goal, we use the SRCB scale (Socially Responsible Consumption Behaviour), which was created by Antil and Bennett (1979) and subsequently tested in three steps in which they eliminated redundant claims. The scale contains forty statements to which the respondent responds with agreement / disagreement, the intensity of which is divided on a 5-point Likter scale. This version of the scale achieved high reliability (Cronbach's alpha $=0.920)$. Overall, the presented tool appears as suitable for further research in the field of ecology and consumer behaviour, so we decided to adapt it in our article. The mean values, standard deviations, and Cronbach's alpha for individual SRCB scale statements were recorded in the Tab. 3. As we used the application of tools in the first and second part of the questionnaire, it was necessary to verify their reliability. Cronbach's alpha is used to investigate the reliability (accuracy and reliability of a research tool) within the internal consistency of the selected scale, while the value of Cronbach's alpha should be in the range of $0.750-0.950$. (Tavakol and Dennick, 2011) As we can see in Table2, the total value of Cronbach's alpha value for ACC scale was 0.813 , which can be interpreted as a high value. We can see in Table 3 that Cronbach's alpha value for SRCB scale is 0.911, which can be interpreted as a very good value. From a practical point of view, it should also be stated that if the Cronbach's alpha value for the individual statements is higher than a total, it is advisable to exclude this statement in future research. As this will increase the overall accuracy and reliability of the research tool - in our case of ACC scale. As we can see, it is not appropriate to rule out any of the statements. In the case of the SRCB scale, it is appropriate to examine arguments 15 and 33 in more detail. The standard deviation of the mean represents the dispersion of the calculated arithmetic mean across the different samples selected from one main population. The standard deviation shows to what extent the individual measured values are around the mean value. The smaller the standard deviation, the closer the measured values are around the mean one. If the variance is smaller, it can be understood that the statement was rated similarly by all respondents. As we can see, respondentsrespondents' answers were more consistent on the ACC scale. 
Tab. 3 SRCB scale

ACC scale items*
1. People should be more concerned about reducing or limiting
the noise in our society.

2. Every person should stop increasing their consumption of products so that our resources will last longer.

3. The benefits of modern consumer products are more important than the pollution which results from their production and use.**

4. Pollution is presently one of the most critical problems facing this nation.

5. I don't think we're doing enough to encourage manufacturers to use recyclable packages.

6. I think we are just not doing enough to save scarce natural resources from being used up.

7. Natural resources must be preserved even if people must do without some products.

8. All consumers should be interested in the environmental consequences of the products they purchase.

9. Pollution is not personally affecting my life.**

10. Consumers should be made to pay higher prices for products which pollute the environment.

11. It genuinely infuriates me to think that the government doesn't do more to help control pollution of the environment.

12. Nonreturnable bottles and cans for soft drinks and beer should be banned by law.

13. I would be willing to sign a petition or demonstrate for an environmental cause.

\begin{tabular}{|c|c|c|}
\hline $\begin{array}{l}\text { Mean } \\
\text { scores }\end{array}$ & $\begin{array}{l}\text { Standard } \\
\text { deviations }\end{array}$ & $\begin{array}{l}\text { Cronbach's } \\
\text { alpha*** }\end{array}$ \\
\hline 2.76 & 1.34 & 0.903 \\
\hline 3.25 & 2.58 & 0.905 \\
\hline 4.19 & 1.63 & 0.907 \\
\hline 2.99 & 2.08 & 0.902 \\
\hline 2.65 & 2.22 & 0.912 \\
\hline 2.29 & 1.27 & 0.906 \\
\hline 2.74 & 1.52 & 0.907 \\
\hline 2.48 & 1.79 & 0.905 \\
\hline 2.11 & 0.87 & 0.907 \\
\hline 2.93 & 1.86 & 0.907 \\
\hline 2.84 & 1.82 & 0.906 \\
\hline 3.35 & 1.77 & 0.909 \\
\hline 2.60 & 1.46 & 0.904 \\
\hline 3.36 & 2.13 & 0.907 \\
\hline 2.58 & 1.60 & 0.905 \\
\hline 2.77 & 2.06 & 0.905 \\
\hline 2.65 & 2.06 & 0.906 \\
\hline 2.43 & 1.30 & 0.906 \\
\hline 2.33 & 1.33 & 0.905 \\
\hline 2.74 & 1.50 & 0.906 \\
\hline
\end{tabular}

14. I have often thought that if we could just get by with a little less there would be more left for future generations.

15. The Federal government should subsidize research on technology for recycling waste products.

16. I'd be willing to ride a bicycle or take a bus to work in order to reduce air pollution.

17. I would probably never join a group or club which is concerned solely with ecological issues.*

18. I feel people worry too much about pesticides on food products. $* *$

19. The whole pollution issue has never upset me too much since I feel it's somewhat overrated.**

20. I would donate a day's pay to a foundation to help improve the environment. 


ACC scale items*
21. I would be willing to have my laundry less white or bright in
order to be sure that I was using a non-polluting laundry
product.
22. Manufacturers should be forced to used recycled materials
in their manufacturing and processing operations.
23. I think that a person should urge his/her friends not to use
products that pollute or harm the environment.
24. Commercial advertising should be forced to mention the
ecological disadvantages of products.
25. Much more fuss is being made about air and water pollution
than is really justified.*

26. The government should provide each citizen with a list of agencies and organizations to which citizens could report grievances concerning pollution.

27. I would be willing to pay a $5 \%$ increase in my taxes to support greater governmental control of pollution.

28. Trying to control water pollution is more trouble than it is worth.**

29. I become incensed when I think about the harm being done to plant and animal life by pollution.

30. People should urge their friends to limit their use of products made from scarce resources.

31. I would be willing to pay one dollar more each month for electricity if it meant cleaner air.

32. It would be wise for the government to devote much more money toward supporting a strong conservation program.

33. I would be willing to accept an increase in my family's total expenses of $50 €$ next year to promote the wise use of natural resources.

34. Products which during their manufacturing or use pollute the environment should be heavily taxed by the government.

35. People should be willing to accept smog in exchange for the convenience of automobiles.*

36. When I think of the ways industries are polluting I get frustrated and angry.

37. Our public schools should require all students to take a course dealing with environmental and conservation problems.

38. I would be willing to stop buying products from companies guilty of polluting the environment even though it might be inconvenient.

39. I'd be willing to make personal sacrifices for the sake of slowing down pollution even though the immediate results may not seem significant.

\begin{tabular}{|c|c|c|}
\hline $\begin{array}{l}\text { Mean } \\
\text { scores }\end{array}$ & $\begin{array}{l}\text { Standard } \\
\text { deviations }\end{array}$ & $\begin{array}{l}\text { Cronbach's } \\
\text { alpha*** }\end{array}$ \\
\hline 2.50 & 1.79 & 0.905 \\
\hline 3.20 & 2.59 & 0.904 \\
\hline 2.72 & 1.81 & 0.904 \\
\hline 3.38 & 2.15 & 0.908 \\
\hline 2.65 & 2.05 & 0.905 \\
\hline 2.43 & 1.28 & 0.905 \\
\hline 3.21 & 2.03 & 0.903 \\
\hline 2.95 & 2.16 & 0.906 \\
\hline 3.00 & 2.66 & 0.906 \\
\hline 2.55 & 1.66 & 0.906 \\
\hline 3.20 & 2.26 & 0.91 \\
\hline 2.51 & 2.00 & 0.908 \\
\hline 4.19 & 1.55 & 0.913 \\
\hline 3.01 & 1.21 & 0.907 \\
\hline 3.02 & 0.89 & 0.908 \\
\hline 3.91 & 0.08 & 0.909 \\
\hline 3.49 & 0.25 & 0.909 \\
\hline 2.62 & 1.07 & 0.906 \\
\hline 2.52 & 1.14 & 0.904 \\
\hline
\end{tabular}




\begin{tabular}{l|l|l|l}
\hline ACC scale items* & $\begin{array}{l}\text { Mean } \\
\text { scores }\end{array}$ & $\begin{array}{l}\text { Standard } \\
\text { deviations }\end{array}$ & $\begin{array}{l}\text { Cronbach's } \\
\text { alpha*** }\end{array}$ \\
\hline $\begin{array}{l}\text { 40. I rarely ever worry about the effects of smog on myself and } \\
\text { family.** }\end{array}$ & 2.66 & 1.18 & 0.906 \\
\hline
\end{tabular}

Note: * Used 5-degree Likert scale (1 = strong disagreement, 5 = strong agreement).

$* *$ Negative / opposite evaluation.

$* * *$ Overall Cronbach's alpha $=0.911$

Source: Own calculations based on a scale from Antil and Bennett, 1979

The last part of the questionnaire was focused on the identification of respondents (age, gender, and residence).

\section{RESULTS AND DISCUSSION}

\subsection{Results}

In the primary research we used a quantitative method to collect data. We conducted a standardized query using a research tool - the questionnaire. To achieve the main goal, we focused on solving partial goals, based on which we formulated hypotheses and research questions. In the next section we focus on answering research questions and verifying hypotheses.

\section{RQ1: What is the rate of attitudes towards climate change? (based on ACC scale)}

The scale used for the measurement contained 12 statements, with the respondent commenting on 5 points of the Likert type scale for each one. It follows that the resulting value can range from 5 to 60 points. The average value measured by us is 29.45 points (approximately $44.45 \%$ ), which is below average to the average value (the average of the scale is 32.5 points). The average calculation error is 0.433 points. The modus represents a value of 22 points and a median 28 points. Overall, we rate of the ACC scale in Slovakia as below-average / average.

RQ2: What is the level of ecologically and socially responsible consumption? (based on SRCB)

The average of SRCB investigated accounted for 115.77 points that is below the average in scale (scale average $-120 ;\langle 40,200\rangle$ scale). The average calculation error is 1.23 points. The modus represents a value of 128 points and a median 121 points. Overall, we rate the SRCB as below-average to average.

RQ3: What effect do the selected demographic factors have on the ACC scale?

H1a: There is a relationship between the measured ACC value and age.

H1b: There is a relationship between the measured ACC value and gender.

Age and gender were chosen as the selected demographic factors. Already the initial results suggest that there are significant differences. Males achieved an average ACC score of 26.32 points (st. dev. $=3.64$ ) and females achieved an average ACC score of 32.42 points (st. dev. $=10.47)$. As we can see, the men's segment achieved a more consistent response.

From the point of view of age differences, we examined 3 segments, namely 15-39 years old, 40-64 years old and older than 65 years. Respondents between the ages of 15-39 achieved an average ACC score of 27.91 points with a standard deviation of 9.92 points. Respondents aged 40-64 achieved an average score of 33.40 points (st. dev. $=5.42$ ) and respondents older than 65 years achieved an average ACC value of 23.87 points (st. dev. 6.26). 
However, these results can only be understood as indicative. An important step is to test the hypotheses, which we did with the help of the ANOVA test. We recorded significant test results in Tab. 4.

Tab. 4 Hypotheses H1 Evaluation Results (ANOVA)

\begin{tabular}{|l|l|l|l|l|l|l|}
\hline & F - value & F - crit. & F-F crit. & alpha & p-value & alpha - p-value \\
\hline H1a & 42.598 & 3.019 & F > F crit. & 0.05 & 0.000 & Alpha > P-value \\
\hline H1b & 57.049 & 3.866 & F > F crit. & 0.05 & 0.000 & Alpha > P-value \\
\hline
\end{tabular}

Source: own calculations

Based on the results given in Tab. 4 ( $F>$ FCritical), hypotheses $\mathrm{H} 1 \mathrm{a}$ and $\mathrm{H} 1 \mathrm{~b}$ can be confirmed. The confirmation of the hypotheses is also supported by the fact that Alpha> P-value. This can be rejected as only a noise or a random factor, and we confirm the selected demographic factors (age and gender) as factors influencing attitudes towards climate change.

RQ4: What effect do the selected demographic factors have on the SRCB scale?

H2a: There is a relationship between the measured value of the SRCB and age.

$H 2 b$ : There is a relationship between the measured value of SRCB and gender.

We examined two demographic factors - age and gender. The average score of men was 107.45 points with a standard deviation of 26.89 points and the average score of women was 123.56 points with a standard deviation of 17.92 points.

In terms of age difference, it can be stated that consumers aged 40-64 achieved the highest average score (average 125.77 points with a standard deviation of 17.24 points), followed by a segment of 15-39-year-old (average 113 points with a standard deviation of 25.97 points) and the lowest average score was obtained by consumers over 65 (average 98.42 points, st. dev. 22.05).

These results can be understood as indicative and therefore no clear conclusion can be drawn from them. Therefore, we decided to test the hypotheses based on the ANOVA test (see Tab. $5)$.

Tab. 5 Hypotheses H2 Evaluation Results (ANOVA)

\begin{tabular}{|l|l|l|l|l|l|l|}
\hline & F - value & F - crit. & F-F crit. & alpha & p-value & alpha - p-value \\
\hline H2a & 38.933 & 3.019 & F > F crit. & 0.05 & 0.000 & Alpha > P-value \\
\hline H2b & 47.494 & 3.866 & F > F crit. & 0.05 & 0.000 & Alpha > P-value \\
\hline
\end{tabular}

Source: own calculations

Based on the results given in Tab. 5 (F> Fcritical), hypotheses $\mathrm{H} 2 \mathrm{a}$ and $\mathrm{H} 2 \mathrm{~b}$ can be confirmed. The confirmation of the hypotheses is also supported by the fact that Alpha> P-value. This can be rejected as only a noise or a random factor. And we confirm the selected demographic factors (age and gender) as factors influencing socio-ecological conscious consumption.

RQ5: What is the direction and intensity of the relationship between ACC scale and SRCB scale?

H3: There is a relationship between the ACC value and the SRCB.

To confirm (refuse) the hypotheses we chose the ANOVA one-way test. Based on the test, it can be stated that the F-value > F crit. value, hypothesis can be confirmed (in all cases). 
Confirmation of the hypothesis is also supported by the fact that alpha (0.05) > P-value. In this way, it can be rejected that it was just a noise. We confirm that there is a relationship between ACC values and SRCB values. We used regression analysis to determine the direction and magnitude of this relationship (see Tab. 6).

Tab. 6 Results of regression analysis

\begin{tabular}{|l|l|l|l|l|l|l|l|}
\hline & \multicolumn{3}{|l|}{ Regression Statistics } & \multicolumn{2}{l|}{ ANOVA } & \multirow{2}{*}{$\begin{array}{l}\text { Regression } \\
\text { function }\end{array}$} \\
\cline { 2 - 7 } & $\begin{array}{l}\text { Multiple } \\
\text { R }\end{array}$ & $\begin{array}{l}\text { R } \\
\text { Square }\end{array}$ & $\begin{array}{l}\text { Standard } \\
\text { Error }\end{array}$ & Alpha & $\begin{array}{l}\text { P- } \\
\text { value }\end{array}$ & Significance F & \\
\hline H3 & 0.731 & 0.534 & 16.46 & 0.05 & 0.000 & 0.000 & positive \\
\hline
\end{tabular}

Source: own processing

We can see a positive relationship between ACC values and SRCB values. In ANOVA, we test a null hypothesis that claims the model we have chosen to explain dependence (in our case linear regression line) is not appropriate (the alternative hypothesis argues the opposite). The $F$ test is used to evaluate this claim. The significance $F \leq 0.05$ ( $a$ - significance level) that means that the model has been selected correctly. The null hypotheses that are tested in this analysis relate to the significance of the locating constant and the regression coefficient with the null-hypothesis asserting the insignificance of the relevant coefficient and the alternative hypothesis of its significance. The P-value for the locating constant is less than 0.05 (alpha), this suggests that the locating constant is statistically significant. As we can see, this is a strong relationship (Multiple $r=0.731$ ), with the selected regression line explaining revenue variability to approximately $53 \%$. Error (16.464) is acceptable given the depth of the variables examined. The regression function has a positive character. It can be stated that the more positive the rate of attitude towards climate change (ACC), the higher the level of sociological-ecological awareness (SRCB) among respondents.

\subsection{Discussion}

The results of the primary are comprehensive. We have shown that consumers have an average attitude towards climate change. While some are strongly positive, consumers are also diametrically opposed, creating overall average results. The scale captures mainly the cognitive (cognitive) dimension, which needs to be increased. Overall, it can be stated that from the point of view of ecological education and ecologically responsible behaviour, it is necessary to increase this number. This can be achieved e.g., consumer education and further complementary education.

The authors Čvirik - Ölveczká (2020a) concluded that "Slovaks have an average knowledge of the subject, and also achieve an average level of willingness to address (or mitigate the impacts) of climate change." We came to the same conclusion.

As we can say, women are more positive about climate change, which may be due to their higher interest in ecology, which is also linked to climate change. Respondents aged 40-64 reached the highest average ACC scale, which may be due to the fact that this is a generation that has enough information (from different fashions) and is also aware of its role in the ecological system. Respondents aged 15-39 achieved a lower score, who, although they have enough information, form their own opinions, which may not be exactly identical with the ecological intention. The $65+$ generation did not have a relationship with ecology at a younger age, when ecological problems did not recur as often as they do today. It is therefore logical that it achieves the lowest average rate on the ACC scale. We believe that increasing the 
knowledge component would also increase the rate of ACC, but it is necessary to choose the right communication strategy and media mix for each segment.

Socially and environmentally responsible consumption is currently one of the most important topics of conscious consumer behaviour.

From the available sources it can be stated that the topic of responsible consumption and ecological awareness in consumer behaviour in the conditions of Slovakia was dealt with by the authors Čvirik - Ölveczká (2020b), who measured a below-average level on the basis of SCRB. As we found out, the rate of the SRCB is currently on average to below average. It is necessary to increase this rate. From the point of view of individual statements of the scale, it can be stated that Slovak consumers feel that they are doing enough to protect scarce resources. At the same time, they have insufficient information about environmental consequences on the consumption of certain products; that pollution and pesticides do not affect their lives, which poses a direct risk to health.

It can be stated that women have more socially responsible consumption and are more aware of the environmental impact of consumption than men.

From the point of view of age, the lowest socially responsible consumption is achieved by respondents over 65 years of age, followed by respondents from 15 to 39 years of age, and the highest level of social and environmental responsibility is achieved by consumers between 40 and 64 years of age. The reason may be several, whether the time in which the generations live, the degree of ecological awareness, or interest in the issue.

Although the ACC and SRCB scale examine environmental issues from different perspectives, it can be stated that there is a strong positive relationship between them. This is a logical interpretation, as both concepts examine environmental and ecological aspects, while at a higher value, higher ecological awareness can be stated.

\section{CONCLUSION}

The aim of the article was fivefold: (1) measuring Slovaks' attitudes to climate change (based on Attitudes to Climate Changes Scale), and also (2) examining the influence of demographic factors on this rate, (3) measuring socio-ecological behaviour of Slovaks (based on Socially Responsible Consumption Behaviour Scale), as well as (4) examining the impact of demographic factors on this rate. At the same time, we would examine (5) the relationship of Slovaks' attitudes to climate change and their socio - ecological behaviour.

Based on the primary survey, it can be stated that the average value of both examined scales (ACC and SRCB) reaches below-average to average level. This result can serve as a basis for further research. It is necessary to realize that environmental conditions are constantly deteriorating, and it is also up to individuals to contribute their awareness of the issue to the one that will ultimately bring an increase in the quality of life.

It is possible to state the significance of demographic factors - age and gender - on the researched concepts. These results can be used mainly in communication, whether in the creation of communication strategies or in general in the creation of a communication policy that focuses on increasing the level of environmental awareness. Men and consumers over the age of 65 can be identified as critical segments in this area.

In the future, it would be appropriate to examine other demographic factors, but also psychological-behavioural ones, which would help in more accurate segmentation of consumers and thus identify potential critical segments that need to be worked with (raising awareness). At the same time, it would be appropriate to create a model that would contribute to raising awareness (environmental, social, and environmental). 
The results of the work can be used both in marketing areas (product, price, distribution, and communication), as well as in consumer behaviour and consumer policy.

\section{REFERENCES}

Abdul Wahid, N., Rahbar E., \& Shyan, T. S. (2011). Factors influencing the green purchase behavior of Penang environmental volunteers. International Business Management, 5(1), 3849. https://doi.org/10.3923/ibm.2011.38.49.

Antil, J.A. (1984). Socially Responsible Consumers: Profile and Implications for Public Policy. Journal of Macromarketing, 18-39. https://doi.org/10.1177/027614678400500203.

Antil, J. A., \& Bennett, P. D. (1979). Construction and Validation of a Scale to MeasureSocially Responsible Consumption Behavior. Chicago: American Marketing Association, Karl H. Henion II and Thomas C. Kinnear, The Conserver Society, 51-68. ISBN: 0877571279.

Badzińska, E. (2011). Konkurowanieprzedsiębiorstw w segmenciemłodychkonsumentów. Publisher: PolskieWydawnictwoEkonomiczne. 1st ed., 164pp. ISBN: 978-83-208-1960-1.

Binninger, A.S., \& Robert, I. (2008). Consommation et développement durable: versune segmentation des sensibilités et des comportements. La Revue des Sciences de Gestion, Direction et Gestion, 1(229), 51-59. ISBN: 9782916490113. https://doi.org/10.1051/larsg:2008006.

Chan, R.Y.K. (1998). Environmental attitudes and behavior of consumers in China: Survey Findings and Implications. Journal of International Consumer Marketing, 11(4), 25-52. https://doi.org/10.1300/J046v11n04_03

Courtenay-Hall, P., \& Rogers, L. (2002). Gaps in Mind: problems in environmental knowledgebehaviour modelling research, Environmental Education Research, 8(3), 283-297. https://doi.org/10.1080/13504620220145438

Čvirik, M. \& Ölveczká, D. (2020a). Postoj Slovákov ku klimatickým zmenám: Konštrukcia a validácia ACCscale. Ekonomika cestovného ruchu a podnikanie, 12(1), 6-14. ISSN 2453-9988.

Čvirik, M. \& Ölveczká, D. (2020b). Zodpovedná spotreba a ekologická uvedomelost' v spotrebitel'skom správaní $\mathrm{v}$ podmienkach Slovenska. Ekonomika cestovného ruchu a podnikanie, 12(1), 15-22. ISSN 2453-9988.

Diekmann, A. \& Franzen, A. (1997). Einsicht in ökologische Zusammenhänge und Umweltverhalten. CO2 - Eine Herausforderungfür die Menschheit, Springer, Berlin, Heidelberg, 120-138. ISBN: 978-3-642-60545-1. https://doi.org/10.1007/978-3-642-60545-1_9.

Fliegenschnee M. \& Schelakovsky M. (1998). Umweltpsychologie und Umweltbildung: Eine Einführungaushumanökologischer Sicht, 168pp. FacultasUniversitäts Verlag, Wien. ISBN: 9783-850-76449-0.

Gough, S. (2002). Whose Gap? Whose Mind? Plural Rationalities and Disappearing Academics. Environmental Education Research, 8(3), 273-282. https://doi.org/10.1080/13504620220145429

Kraiciné Szokoly, M. \& Czippán K. (2011). A fenntartható fogyasztásra nevelés kérdései: Tanulmányok a képzésés kommunikáció területéröl. Corvinus University of Budapest. 128pp. ISBN: 9789633390115.

Mohr, L.A., Webb, D. J., \& Harris, K.E. (2001). Do Consumers Expect Companies to be Socially Responsible? The Impact of Corporate Social Responsibility on Buying Behavior. Journal of Consumer Affairs, 35(1), 45-72. https://doi.org/10.1111/j.1745-6606.2001.tb00102.x. 
Roberts, J.A. (1995). Profiling levels of socially responsible consumer behavior: A cluster analytic approach and its implications for marketing. Journal of Marketing Theory and Practice, 3(4), 97-117. https://doi.org/10.1080/10696679.1995.11501709.

Roberts, J.A. (1996a). Green consumers in the 1990s: Profile and implications for advertising. Journal of Business Research, 36(3), 217-231. https://doi.org/10.1016/0148-2963(95)001506.

Roberts, J.A. (1996b). Will the real socially responsible consumer please step forward? Business Horizons, 39(1), 79-83. https://doi.org/10.1016/S0007-6813(96)90087-7.

SOSR (2020). STATISTICAL OFFICE OF THE SLOVAK REPUBLIC. ŠTATISTICKÝ ÚRAD SLOVENSKEJ REPUBLIKY. Retrieved April 30, 2020, from http://datacube.statistics.sk/\#!/view/sk/SODB/hc1okr/Obyvate\%C4\%BEstvo\%20pod\%C4\%B Ea\%20miesta\%20s\%C4\%8D\%C3\%ADtania,\%20pohl.,\%20postav.\%20v\%20dom\%C3\%A1c. ,\%20rodinn.\%20stavu,\%20ekonom.aktivity,\%20miesta\%20narod.,\%20\%C5\%A1t\%C3\%A1t .\%20pr\%C3\%ADslu\%C5\%A1.\%20a\%20veku\%20-\%20HC1.

Sua, J.C.P., Wang, L., \& Ho, J.C. (2012). The impacts of technology evolution on market structure for green products. Mathematical and Computer Modelling, 55(3-4), 1381-1400. https://doi.org/10.1016/j.mcm.2011.10.017.

Székely, M., Polgár, E., \& Takács S. (2011). Values and Culture of Sustainable Consumption. Sustainable Consumption Production and Communication Conference, 21. January, 2011, Budapest. Retrieved July 10, 2020, from http://www.sustainable.consumption.unicorvinus.hu/fileadmin/user_upload/hu/tanszekek/gazdalkodastudomanyi/t_kornyezetgazdasa g/norveg/k-tar-4/4-1-Szekely_Values-and-culture-of-sustainable-consumption.pdf.

Tavakol, M. \& Dennick, R. (2011). Making sense of Cronbach's alpha. International Journal of Medical Education, 2(53-55). https://doi.org/10.5116/ijme.4dfb.8dfd.

Webster, F. E. Jr. (1975). Determining the characteristics of the socially conscious consumer. Journal of Consumer Research, 2(3), 188-196. https://doi.org/10.1086/208631.

Zakersalehi, M., \& Zakersalehi, A. (2012). Consumers' attitude and purchasing intention toward green packaged foods; A Malaysian perspective. 2012International Conference on Economics Marketing and Management, 28, IACSIT Press, Singapore. 